\title{
情報技術の進歩と健診への応用
}

\section{大阪府立健康科学センター 健康度測定部}

岡田武夫

\section{1 . 情報技術の進歩}

情報技術（ＩＴ）の最近の進歩は、インターネットに代表される「ネットワーク化」である。 インターネットなどのネットワークを介することで、いつでもどこからでも種々の情報にアプロ 一チすることが可能になった。このネットワークを活用することで、健診の在り方が大きく変わ る可能性がある。

高性能高機能のコンピュータが安価で手に入るようになった結果、音声、静止画、動画などを 他のデータと統一的に取り扱うことができるようになった。このマルチメディア化によって、コ ンピュータが単なる事務機器ではなく、マルチメディア情報の編集・表示機能を持つことになっ た。

最近では、ADSL (Asymmetric Digital Subscriber Line) や CATV (Cable Television) など の手段で、インターネットへの高速かつ常時接続が容易にできるようになった。さらに、e-Japan 重点計画によれば、 5 年以内に超高速アクセスが可能な世界最高水準のインターネット網が整備 されるという。すなわち、マルチメディアデータなど、大量のデータをインターネット上でやり とりすることが、低コストで可能となった。

ネットワーク上で情報を安全に交換するためには、情報の暗号化などの方策でセキュリティを 確保する必要がある。ネットワークで用いる暗号方式としては、公開鍵暗号方式が利便性と機密 性を両立しうる手段として一般的である。公開鍵暗号方式を使うためには、公開鍵を管理し、公 開鍵の持ち主を認証する機構が必要である。このような機構を P K I （Public Key Infrastructure）と呼ぶが、日本でも e-Japan 構想などとともにその整備が本格的に始まろうと している。

コンピュータの小型化は、i-mode 携帯電話や PDA (Personal Data Assistants) などの携帯端 末の発達をもたらした。これらを利用することで、外出先などからインターネットにアクセスし たり、メール交換をすることが容易となった。

保険証の IC カード化など、日本でも IC カードの利用が徐々に広がりつつある。IC カードを データの保存や運搬の媒体として使うことに関しては、紛失時などセキュリティの問題から議論 の余地がある。したがって、当面は IC カードを個人認証のカギとして使うなどの方法が一般的 となろうが、ネットワークと IC カードを組み合わせて使うことで、遠隔地からの情報へのアク セスや、情報の交換を安全に行うことが可能となる。

用語の標準化は、学会毎の用語集の作成から始まり、急速に整備されつつある。ネットワーク を用いて情報を交換するためには、用語の標準化とともにコード化が必要である。現在では、具 体的にどのようなコードを用いるかなどの課題がある。

2 . 健診機器の高度化

コンピュータの発達により、元来二次元の画像である CT ゃ MRI、超音波の画像を合成して、 
立体感のある三次元の画像とすることが容易になった。さらに、視点を変えることや動画として 観察することも容易となってきた。このような手法を用いることで、病変の正確な性状や周囲の 臓器との関連を把握することが容易となる。

従来はフィルムを用いていた X 線写真もデジタル化が可能となった。デジタル化することで、 保管スペースの縮小や検索が容易になる、などのメリットがある。さらに、検体検査など他の情 報と一括して管理することで、より正確な診断や経過観察が可能となる。

このように、健診機器が高度化することで、これまでは健診という場では不可能であった、よ り精密な検查が可能となる可能性がある。コストや診断に要する人的資源の問題はあるものの、 各種の高度な診断機器が健診の場に入ってくることであろう。

\section{3 . 健診情報の利用}

健診の情報を集積することで、日本における疾病の発生状況の変化など、各種の疫学的な調查 が可能となる。一方で、医療の現場では、患者などへの情報公開が広く求められている。また、 治療内容のわかりやすい説明も求められている。これらの情報の一部は、疫学的な調査によって 得られる。特に、EBM（Evidence Based Medicine）のための資料を作成することは、これか らの日本の医療の発展に不可欠である。

生活習慣病の増加と高齢化に伴って、一病息災という言葉が示すように、健診の現場でも各種 疾患を持った人を取り扱う機会がこれからも増加するであろう。健診は、疾病の予防と早期発見 という観点から行われるのであるが、生活習慣病の医療は、生活習慣病の進展による新たな疾患 の発生を予防する（二次予防）という側面がある。したがって、将来の医療は、予防と治療がこ れまで以上に密接に連携していくことが求められている。すなわち、健診と医療の密接な連携が 求められている。

医療の I T化に伴い、健診で発生するデー夕を医療機関で活用し、また、医療機関の情報を健 診時に参照することが、これからは求められよう。そのためには、各種検査の標準化をはじめ、 様々な分野での標準化が肝要となろう。地域や職域と言った壁を越えた連携を実行するためにも、 標準化は重要な課題である。

\section{4. 健診の将来}

これまで述べてきたように、情報技術（ＩＴ）の発達は、場所や時間の制約にとらわれること なく、画像を含めた各種の情報を交換することを可能とした。また、各種の健診機器の高度化な ど、健診の手段の高度化ももたらした。

健診がもたらす情報は、ミクロでは個人の健康状態を表す情報に過ぎないが、これを集成する ことでマクロのデータとすることができる。健診そのものの意義を啓蒙するためにも、医療福祉 政策を考える基礎的な情報としても、マクロの研究・分析は重要な作業である。情報化は、これ らの作業をより容易に広範囲に深く行うことを可能とする。

また、I T化に伴い、医療機関との情報の交換が容易となろう。このことは、健診と医療機関 の連携をより密接にする効果がある。

これらの例に見るように、情報技術の進歩を健診に応用することは、現在、健診や医療に求め 
られている課題を解決することにつながるであろう。一方で、情報技術の進展により、これまで と健診の在り方が変容を迫られる可能性がある。

受診者がそれぞれの要求にマッチした健診を受けようとすると、一つの健診機関ではそのすべ てをまかないきれない事態が起こりうる。受診する時間や場所を受診者が自由に選択することが できれば、それは受診者の利便性を上げ、受診率の向上につながる可能性がある。これらの実現 のためには、複数の健診機関が連携することが必要である。そして、I T 化は連携を可能とする。 しかし、情報交換や連携にあたっての障害もある。問診票一つをとっても、健診機関により千 差万別であり、そこからもたらされる情報もまた違ったものとなっている。検査の方法などが標 準化されていないために、検査数值をそのまま利用できないこともあろう。このように、標準化 がされていないことが、複数の健診機関の間や医療機関との情報の交換や連携を拒む要因となり うる。

このように、複数の機関が連携する必要性は、今後高まると考えられる。I T化はそれを可能 とする。標準化が進展しないことはその阻害要因となりうるが、連携する必要性が広く認識され れば、標準化が促進されるであろう。しかし、連携するか否かは、I T とは直接関係のない問題 である。この辺りが、I Tを健診へ応用する際の課題となろう。

Information and communication is not technical matter but political issue. 